\title{
ANALYSIS OF DIFFERENT TYPE USA MUTUAL FUNDS PERFORMANCE EVALUATION IN THE PERIOD OF 2000-2010
}

\author{
Lina Žalgiryte் ${ }^{1}$, Andrius Guzavičius ${ }^{2}$ \\ ${ }^{1}$ Kaunas University of Technology, Lithuania, lina.zalgiryte@ktu.lt, \\ ${ }^{2}$ Kaunas University of Technology, Lithuania, andrius.guzavicius@ktu.lt \\ crossref http://dx.doi.org/10.5755/j01.em.17.4.2992
}

\begin{abstract}
The aim of this paper is to compare different risk - adjusted performance measures in different market conditions to see whether these measures lead to the same ranking of mutual funds despite the situation in the market. In this paper, we used the data collected for U.S. mutual funds that invest only in domestic market. Those mutual funds used include equity, index, bond and balanced funds. The empirical investigation focuses on the period of 2000 - 2011. At that time, there were two stock market meltdowns, in 2001 and in 2007 - 2008, which had a significant impact on mutual fund performance. We used four performance evaluation measures: Modigliani \& Modigliani RAP, Graham - Harvey 1, Treynor ratio and Jensen alpha. The research methods applied include correlation and comparative analysis. We test the correlation and its significance among these measures. We also compare the performance of chosen mutual funds with results of T-Bills and S\&P500 index to see the differences in evaluation. Results show that there is a dependence on year of analysis while evaluating the performance of bond funds compared to results of index, equity and balanced funds. Comparison of mutual fund performance with S\&P500 Index and 3 month T-Bills show that there are pairs of measures which evaluate equity, index and balanced funds similarly. There are more differences in bond fund evaluation.

Keywords: mutual fund, portfolio performance, risk - adjusted measures, correlation analysis.

JEL Classification: G11, G23.
\end{abstract}

\section{Introduction}

Today private investors are offered a wide variety of investment options with the opportunity to invest not only in domestic but also in foreign markets. One of the most popular investment options is mutual fund. The importance of mutual fund industry has grown in recent decades. The worldwide total net assets invested in mutual funds more than doubled from 11,8 TUSD in 1999 to 24,7 TUSD in 2010 and the number of mutual funds worldwide increased from 52746 in 1999 to 69519 in 2010 (The Investment Company Institute [ICI], 2006, 2011). The U.S. mutual fund market is the largest in the world. This market alone accounts for 48 percent of the mutual fund net assets worldwide while the whole European mutual fund market accounts for 52 percent of worldwide net assets (ICI, 2011). Thus, the situation in U.S. fund market influences the whole world. In comparison with U.S. Lithuanian mutual fund market is young; it began its development only in 2001 with NSEL 30 Index Fund now known as OMX Baltic Benchmark Fund. In 2010 the number of mutual funds established in Lithuania reached 38 with the total net asset of 602,02 MLTL or 174,36 MEUR (The Securities Commission of the Republic of Lithuania [LSC], 2010).

The main aim of any investor is to find investment strategy with maximum return. To achieve this goal, investor evaluates different portfolios and compares the results with possible alternative instruments. Literature discusses a number of different performance evaluation methods. One method that private investors often come across is the fund rate of return and risk analysis. However, performance evaluation based on average portfolio returns is useful as long as these returns are risk adjusted. Techniques of risk adjusted performance evaluation were introduced in 1960s with Capital Asset Pricing Model (CAPM). Since then number of theoretical and practical studies has been conducted examining the performance of mutual funds. Most of these studies could be divided into three groups:

- tests of fund manager's stock - selection, market - timing abilities (see for instance Chen et al. (2010), Fletcher (1995), Glassman \& Riddick (2006), Henriksson \& Merton (1981), Jiang et al. (2007), Merton (1981), and others);

- analysis of fund characteristics such as fees, past performance, fund family, etc., and fund performance (see for instance Elton et al. (2007), Indro et al. (1999), Massa M. (2003), Pollet \& Wilson (2008), Prather et al. (2004) and others);

- persistence of fund performance (Brown \& Goetzmann (1995), Carhart, (1997), Chevalier \& Ellison (1999), Davis (2001), Huij \& Verbeek (2007), Hendricks et al. (1993) and others).

This paper cannot be attached to one specific group from those mentioned above. We focus on comparison of different performance measures rather than fund performance. One can find publications 
presenting different performance measures and their relations or differences. For instance, Modigliani \& Modigliani (1997) pointed the differences of their proposed measure RAP/RAPA, Sharpe, Jensen - Treynor measures. They note that "[t]he portfolio that is best by RAP criteria is also best by Sharpe ratio (and conversely". Cogneau \& Hubner (2009) presented a census of more than one hundred performances measures, which "are categorized based on the general way they are computed". Scholz \& Wilkens (2005) presented a system of some basic performance measures explaining the links and showing differences between them. Eling \& Schuhmacher (2007) concluded that "the choice of performance measure does not have a crucial influence on the relative evaluation of hedge funds". Simons (1998) compares rankings of a sample of mutual funds using Sharpe ratio and Morningstar star ratings. She finds a strong correlation between these measures for stock and bond funds in the period of 1995 - 1997. Empirical investigation on some risk measures has shown that "[e]very risk measure delivered a different ranking of the business days of the year 1999" (Hahn et al., 2002). The novelty of our paper is the comparison of different risk - adjusted performance measures in different market conditions. Thus the research objective is risk - adjusted performance measures. The aim of this paper is to analyze whether these measures lead to same ranking of mutual funds despite the situation in the market. Hence the research tasks are:

- to measure portfolio performance of equity, index, bond and balanced mutual funds in U.S. with alternative measures over the period of 1999-12-31 - 2010-12-30;

- to test the correlation and its significance among different measures;

- to test whether evaluation results depend on year of analysis / market situation;

- compare portfolio performances of equity, index, bond and balanced mutual funds with T-Bills and S\&P500 Index to see the differences in evaluation. analysis

The research methods applied include analysis of scientific literature, correlation and comparative

\section{Data and methodology}

The empirical investigation focuses on the period of 1999-12-31 - 2010-12-30, i.e. 11 years of daily data. During this time, the periods of economic recession in U.S. were identified twice: March - November, 2001 and December, 2007 - June, 2009. This can be seen in S\&P 500 Index chart in Figure 1 where grey areas mark U.S. recession periods. There were two stock market meltdowns in 2001 and in $2007-2008$, which had a significant impact on fund performance.

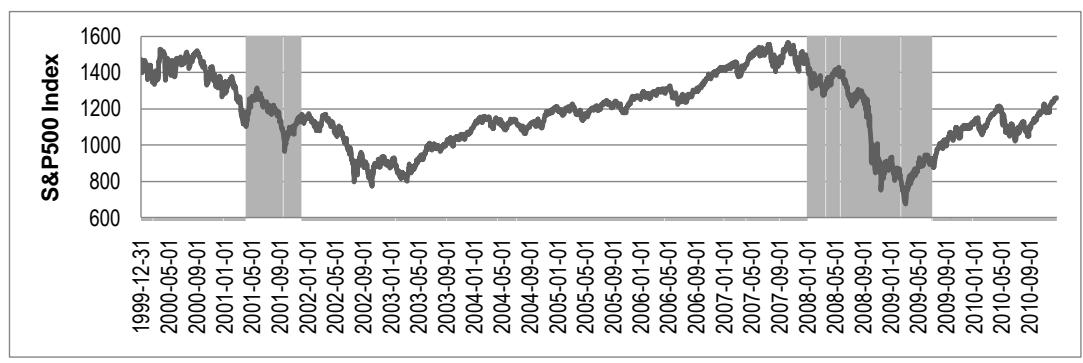

Data sources: NBER, Yahoo! Finance

Figure 1. S\&P 500 Index and U.S. recession periods 2000-2010

As shown different stock market conditions were evident during the time period used in this research. The periods are as follows:

- long downward period in 2000-2003 caused by the burst of IT bubble and September $11^{\text {th }}$ attacks on the World trade centre.

- market recovering in 2003-2006;

- high market volatility till mid 2007 and dramatic decline in mid 2007-2009;

- market recovering in mid 2009-2010.

Signs of the 2007-2011 financial crisis occurred in the U.S. in 2006 with falling real estate prices and the start of the mortgage default. The beginning of the global crisis is considered the moment when economy 
in many countries turned in recession. The collapse of the financial system came in 2008. In U.S. 2007 2009 financial situation is considered the largest financial disruption since the Great Depression in 1929 1933. The net asset value of mutual fund industry declined by 8,3 TUSD.

In this paper, we used the data collected for U.S. mutual funds that invest only in domestic market. No focus was put on foreign bond, equity funds, since there are differences in regulations, exchanges rates and foreign risk free rates. We chose mutual funds with portfolios consisting only of equities (stocks), fixed income (bonds) and their composition. So those mutual funds used include 84 equity (Growth), 30 index (Index - Large Cap), 29 bond (Government/Corporate bond) and 10 balanced funds. Here, for a mutual fund qualifying as balanced $\sim 60 \%$ of its total assets are allocated to the stock market and $\sim 40 \%$ to the bond market. Daily (adjusted for dividends) fund data was retrieved from Yahoo! Finance. JPM US Aggregate Bond Index data was supplied by SEB bank. The risk - free rate used in this research is the 3-month U.S. Treasury Bills. Risk - free rates were retrieved from The Board of Governors of the Federal Reserve System.

In order to evaluate the impact of years mention above and stock market conditions on mutual fund performance evaluation we chose to analyze four performance evaluation measures: Modigliani \& Modigliani RAP (RAP), Graham - Harvey 1 (GH1), Treynor ratio, Jensen alpha.

Modigliani and Modigliani introduced a measure of risk - adjusted performance (RAP) in 1997. The idea behind this technique is to shift the fund up or down the capital market line so that its standard deviation is identical to that of the market portfolio. RAP of a fund is measured by the following equation

$$
R A P=\frac{\sigma_{M}}{\sigma_{p}}\left(r_{p}-r_{f}\right)+r_{f}
$$

where

$$
\sigma_{M} \text { - standard deviation (risk) of the market portfolio; }
$$

$\sigma_{p}$ - standard deviation (risk) of the fund;

$r_{p}$ - average fund rate of return during a chosen time period;

$r_{f}$ - average risk - free rate of return during the same period.

The idea behind one performance measure (GH1) developed by Graham and Harvey (1997) is to adjust the market portfolio so that its standard deviation is identical to that of a fund. The difference between the fund return and the adjusted market portfolio return is the performance measure.

$$
G H 1=r_{p}-\left(r_{f}+\frac{\sigma_{p}}{\sigma_{M}}\left(r_{M}-r_{f}\right)\right)
$$

where $\quad r_{M}$-average rate of return of market portfolio during a chosen time period.

Treynor ratio (Treynor, 1965) is calculated as follows

$$
T=\frac{r_{p}-r_{f}}{\beta_{p}}
$$

where $\quad \beta_{p}$ - beta of the fund (fund's risk measure).

Jensen alpha (Jensen, 1968) is the excess return above or below the security market line. Formally,

$$
J=\alpha=r_{p}-\left(r_{f}+\beta_{p}\left(r_{M}-r_{f}\right)\right)
$$

These methods measure the performance relative to the risk but there is a difference in the way of measuring the risk itself. RAP and GH1 are based on total risk measured by standard deviation, while Treynor ratio and Jensen alpha are based on market risk measured by beta factor.

Since we have chosen different fund types, we chose different benchmarks. The equity funds used here invest most of their capital in U.S. large market capitalization stocks, thus the appropriate benchmark index was chosen S\&P500. JPM US Aggregate Bond Index (JPM US AGG) was chosen as a benchmark for bond funds. For balanced funds, the benchmark was constructed as 60\% S\&P500 and 40\% JPM US AGG.

We measure the performance of selected mutual funds with alternative measures and then test whether these measures lead to similar results and whether these results depend on chosen year. This is done by calculating the correlation and its significance among different measures. We use non - parametric Spearman rank correlation coefficient $(\rho)$. We also compare the evaluation of equity, index, balanced funds with S\&P500 Index and bond, balanced funds with 3 month T-Bills to see the differences in evaluation. 


\section{Research findings}

We measured the performance of selected mutual funds using RAP, GH1, Treynor ratio and Jensen alpha and calculated Spearman correlation coefficients and its significance for each pair of these measures.

Table 1. Correlation coefficients for equity funds

\begin{tabular}{|c|r|r|r|r|r|c|}
\hline Year & GH1 \& RAP & GH1 \& T & GH1 \& J & RAP \& T & RAP \& J & T \& J \\
\hline 2000 & $0,9340 * * *$ & $0,9219 * * *$ & $0,9777 * * *$ & $0,9953 * * *$ & $0,9636 * * *$ & $0,9618 * * *$ \\
\hline 2001 & $0,9932 * * *$ & $0,9888 * * *$ & $0,9886 * * *$ & $0,9909 * * *$ & $0,9783 * * *$ & $0,9905 * * *$ \\
\hline 2002 & $0,9892 * * *$ & $0,9533 * * *$ & $0,9649 * * *$ & $0,9585 * * *$ & $0,9479 * * *$ & $0,9814 * * *$ \\
\hline 2003 & $0,9915 * * *$ & $0,9598 * * *$ & $0,9724 * * *$ & $0,9583 * * *$ & $0,9561 * * *$ & $0,9881 * * *$ \\
\hline 2004 & $0,9864 * * *$ & $0,9791 * * *$ & $0,9852 * * *$ & $0,9920 * * *$ & $0,9817 * * *$ & $0,9917 * * *$ \\
\hline 2005 & $0,9847 * * *$ & $0,9922 * * *$ & $0,9995 * * *$ & $0,9943 * * *$ & $0,9816 * * *$ & $0,9911 * * *$ \\
\hline 2006 & $0,9732 * * *$ & $0,9595 * * *$ & $0,9847 * * *$ & $0,9959 * * *$ & $0,9887 * * *$ & $0,9865 * * *$ \\
\hline 2007 & $0,9942 * * *$ & $0,9919 * * *$ & $1,0000 * * *$ & $0,9957 * * *$ & $0,9944 * * *$ & $0,9921 * * *$ \\
\hline 2008 & $0,9592 * * *$ & $0,9505 * * *$ & $0,9895 * * *$ & $0,9811 * * *$ & $0,9462 * * *$ & $0,9622 * * *$ \\
\hline 2009 & $0,9827 * * *$ & $0,9771 * * *$ & $0,9927 * * *$ & $0,9927 * * *$ & $0,9769 * * *$ & $0,9827 * * *$ \\
\hline 2010 & $0,9964 * * *$ & $0,9942 * * *$ & $0,9944 * * *$ & $0,9969 * * *$ & $0,9883 * * *$ & $0,9897 * * *$ \\
\hline \hline $\min$ & 0,9340 & 0,9219 & 0,9649 & 0,9583 & 0,9462 & 0,9618 \\
\hline $\max$ & 0,9964 & 0,9942 & 1,0000 & 0,9969 & 0,9944 & 0,9921 \\
\hline
\end{tabular}

*** Correlation significant at level 0,01

The results for equity funds given in Table 1 suggest that the strength of association for all measures is very strong and statistically significant. Maximum value for $\rho>0,9900$ and minimal value $\rho=0,9219$ (GH1 \& Treynor). For GH1 and RAP, GH1 and Treynor ratio, Treynor ratio and Jensen alpha correlation coefficients slightly declined in years 2000 (the values are, respectively, $\rho=0,9340, \rho=0,9219, \rho=0,9618$ ) and $2008(\rho=0,9592, \rho=0,9505, \rho=0.9622)$. There was a slight decline in correlation between GH1 and Treynor ratio $(\rho<0,9600)$ in 2002, 2003, 2006 and 2008, RAP and Jensen alpha $(\rho<0,9700)$ in 2002, 2003 and 2008. For RAP and Treynor ratio a slight decline can be seen in 2002 and $2003(\rho<0,9600)$. The strongest association is between GH1 and Jensen alpha. The results suggest that there is no significant dependence neither on year of analysis nor market conditions while evaluating the performance of selected equity mutual funds.

Table 2. Correlation coefficients for index funds

\begin{tabular}{|c|c|c|c|c|c|c|}
\hline Year & GH1 \& RAP & GH1 \& T & GH1 \& J & RAP \& T & RAP \& J & $\mathbf{T} \& \mathbf{J}$ \\
\hline 2000 & $0,9991 * * *$ & $0,8683 * * *$ & $0,8625 * * *$ & $0,8749 * * *$ & 0,8696 *** & $0,9982 * * *$ \\
\hline 2001 & $0,9982 * * *$ & 0,9466 *** & $0,9479 * * *$ & $0,9426 * * *$ & $0,9444 * * *$ & $0,9996^{* * *}$ \\
\hline 2002 & $0,9987 * * *$ & 0,9840 *** & $0,9840 * * *$ & $0,9826 * * *$ & 0,9826 *** & $1,0000 * * *$ \\
\hline 2003 & $1,0000 * * *$ & $0,9008 * * *$ & $0,9016^{* * * *}$ & $0,9008 * * *$ & $0,9016^{* * *}$ & $0,9996 * * *$ \\
\hline 2004 & $0,9978 * * *$ & $0,9622 * * *$ & $0,9680 * * *$ & $0,9595 * * *$ & $0,9648 * * *$ & $0,9991 * * *$ \\
\hline 2005 & $0,9951 * * *$ & 0,9973 *** & $0,9982 * * *$ & $0,9960 * * *$ & $0,9907 * * *$ & $0,9964 * * *$ \\
\hline 2006 & $0,9987 * * *$ & $0,9920 * * *$ & $0,9907 * * *$ & $0,9915 * * *$ & $0,9884 * * *$ & $0,9969 * * *$ \\
\hline 2007 & $0,9982 * * *$ & $0,9978 * * *$ & $1,0000 * * *$ & $0,9996 * * *$ & $0,9982 * * *$ & $0,9978^{* * *}$ \\
\hline 2008 & $0,9991 * * *$ & $0,9978 * * *$ & $0,9982 * * *$ & $0,9991 * * *$ & $0,9987 * * *$ & 0,9996 *** \\
\hline 2009 & 0,9996 *** & 0,8060 *** & $0,8131 * * *$ & $0,8055^{* * *}$ & 0,8126 *** & 0,9933 *** \\
\hline 2010 & 0,9973 *** & $0,9631 * * *$ & $0,9462 * * *$ & $0,9497 * * *$ & 0,9310 *** & $0,9920 * * *$ \\
\hline $\min$ & 0,9951 & 0,8060 & 0,8131 & 0,8055 & 0,8126 & 0,9920 \\
\hline $\max$ & 1,0000 & 0,9978 & 1,0000 & 0,9996 & 0,9987 & 1,0000 \\
\hline
\end{tabular}

*** Correlation significant at level 0,01

The results for index funds are given in Table $\mathbf{2}$. There is a strong statistically significant relation between GH1 and RAP, Treynor ratio and Jensen alpha measures, and statistically significant relation tending to moderate ( $\rho$ close to 0,8000 ) for other pairs depending on year of analysis. Maximum value for all measures is over 0,9970 and minimal value is 0,8055 (RAP \& Treynor ). For the pairs of GH1 and RAP, 
Treynor ratio and Jensen alpha Spearman correlation coefficients are the highest. This result was presumable as the first two measures are based on standard deviation and the second two on beta factor. For the pairs GH1 and Treynor ratio, GH1 and Jensen alpha, RAP and Treynor ratio, RAP and Jensen alpha there was a decline in correlation in $2000(\rho<0,8800)$ and the minimal value of correlation coefficient was reached in 2009 ( $\rho<0,8200)$. The results show insignificant dependence on year of analysis and market conditions while evaluating the performance of selected index mutual funds.

Table 3. Correlation coefficients for bond funds

\begin{tabular}{|c|c|c|c|c|c|c|}
\hline Year & GH1 \& RAP & GH1 \& T & GH1 \& J & RAP \& T & RAP \& J & T \& J \\
\hline 2000 & $0,9798^{* * *}$ & $0,9108^{* * *}$ & $0,9192^{* * *}$ & $0,9567 * * *$ & $0,9532 * * *$ & $0,9921 * * *$ \\
\hline 2001 & $0,9980 * * *$ & $0,9852 * * *$ & $0,8635^{* * *}$ & $0,9906 * * *$ & $0,8665 * * *$ & $0,8483 * * *$ \\
\hline 2002 & $0,9754 * * *$ & $0,7271 * * *$ & $0,8158^{* * *}$ & $0,7163 * * *$ & $0,7837 * * *$ & $0,9645 * * *$ \\
\hline 2003 & $0,9926 * * *$ & $0,7901 * * *$ & $0,9980 * * *$ & $0,7975 * * *$ & $0,9906 * * *$ & $0,7921 * * *$ \\
\hline 2004 & $0,9852 * * *$ & $0,8995 * * *$ & $0,9039 * * *$ & $0,9315 * * *$ & $0,9217 * * *$ & $0,9892 * * *$ \\
\hline 2005 & $0,9685 * * *$ & $0,7685 * * *$ & $1,0000 * * *$ & $0,8158 * * *$ & $0,9658 * * *$ & $0,7685 * * *$ \\
\hline 2006 & $0,9931 * * *$ & $0,9941 * * *$ & $0,9956 * * *$ & $0,9936 * * *$ & $0,9852 * * *$ & $0,9946 * * *$ \\
\hline 2007 & $0,9783 * * *$ & $0,9054 * * *$ & $0,9379 * * *$ & $0,9335 * * *$ & $0,9483 * * *$ & $0,8138 * * *$ \\
\hline 2008 & $0,8749 * * *$ & $0,7631 * * *$ & $0,9621 * * *$ & $0,9227 * * *$ & $0,9315 * * *$ & $0,8310 * * *$ \\
\hline 2009 & $0,8522 * * *$ & $0,7882 * * *$ & $0,9956 * * *$ & $0,9281 * * *$ & $0,8163 * * *$ & $0,7591 * * *$ \\
\hline 2010 & $0,9788 * * *$ & $0,6522 * * *$ & $0,6941 * * *$ & $0,6635 * * *$ & $0,6621 * * *$ & $0,5709 * * *$ \\
\hline \hline $\min$ & 0,8522 & 0,6522 & 0,6941 & 0,6635 & 0,6621 & 0,5709 \\
\hline $\max$ & 0,9980 & 0,9941 & 1,0000 & 0,9936 & 0,9906 & 0,9946 \\
\hline
\end{tabular}

*** Correlation significant at level 0,01

The results for bond funds given in Table $\mathbf{3}$ are different from those of equity and index funds. There is a strong statistically significant relation between GH1 and RAP measures, and statistically significant relation ranging from strong to moderate $(\rho<0,8000)$ for other measures depending on year chosen. Maximum value for all pairs is over 0,9900 and minimal value is 0,5709 (Treynor ratio \& Jensen alpha). For GH1 and RAP measures correlation coefficient declined in $2008-2009$. We find a decline from strong to moderate relation in 2010 for GH1 and Jensen alpha, for RAP and Jensen alpha in 2002 and 2010, while for three other pairs of measures we find three years (RAP \& Treynor ratio), four years (Treynor ratio \& Jensen alpha) or six years (GH1 \& Treynor ratio) of such decline. The strongest association is between GH1 and RAP. The results show a more significant dependence on year of analysis and market conditions while evaluating the performance of bond funds compared to index and equity funds.

Table 4. Correlation coefficients for balanced funds

\begin{tabular}{|c|c|c|c|c|c|c|}
\hline Year & GH1 \& RAP & GH1 \& T & GH1 \& J & RAP \& T & RAP \& J & $\mathbf{T} \& \mathbf{J}$ \\
\hline 2000 & $1.0000 * * *$ & $0.9879 * * *$ & $0.9758 * * *$ & $0.9879 * * *$ & $0.9758 * * *$ & $0.9879 * * *$ \\
\hline 2001 & $1.0000 * * *$ & $0.9636 * * *$ & $0.9636 * * *$ & $0.9636 * * *$ & $0.9636 * * *$ & $1.0000 * * *$ \\
\hline 2002 & $1.0000 * * *$ & $1.0000 * * *$ & $1.0000 * * *$ & $1.0000 * * *$ & $1.0000 * * *$ & $1.0000 * * *$ \\
\hline 2003 & $1.0000 * * *$ & $1.0000 * * *$ & $1.0000 * * *$ & $1.0000 * * *$ & $1.0000 * * *$ & $1.0000 * * *$ \\
\hline 2004 & 0.9636 *** & $0.9879 * * *$ & $1.0000 * * *$ & $0.9515 * * *$ & $0.9636 * * *$ & $0.9879 * * *$ \\
\hline 2005 & 0.9636 *** & $0.9636 * * *$ & $1.0000 * * *$ & $1.0000 * * *$ & $0.9636 * * *$ & $0.9636 * * *$ \\
\hline 2006 & $1.0000 * * *$ & $1.0000 * * *$ & $1.0000 * * *$ & $1.0000 * * *$ & $1.0000 * * *$ & $1.0000 * * *$ \\
\hline 2007 & $0.9879 * * *$ & $0.9879 * * *$ & $1.0000 * * *$ & $1.0000 * * *$ & $0.9879 * * *$ & $0.9879 * * *$ \\
\hline 2008 & $1.0000 * * *$ & $1.0000 * * *$ & $0.9879 * * *$ & $1.0000 * * *$ & $0.9879 * * *$ & $0.9879 * * *$ \\
\hline 2009 & $0.9636 * * *$ & $0.9636 * * *$ & $1.0000 * * *$ & $1.0000 * * *$ & $0.9636 * * *$ & $0.9636 * * *$ \\
\hline 2010 & $1.0000 * * *$ & $1.0000 * * *$ & $0.9879 * * *$ & $1.0000 * * *$ & $0.9879 * * *$ & $0.9879 * * *$ \\
\hline $\min$ & 0.9636 & 0.9636 & 0.9636 & 0.9515 & 0.9636 & 0.9636 \\
\hline $\max$ & 1.0000 & 1.0000 & 1.0000 & 1.0000 & 1.0000 & 1.0000 \\
\hline
\end{tabular}

*** Correlation significant at level 0,01

The results for balanced funds given in Table 4 suggest that the strength of association for selected measures is very strong and statistically significant. Maximum value for all pairs $\rho=1,0000$ and minimal 
value $\rho=0,9515$ (RAP \& Treynor ratio). The results show no significant dependence neither on year of analysis nor market conditions while evaluating the performance of balanced funds.

The results of fund performance in comparison with S\&P500 Index and 3 month T-Bills are shown in

Table 5 and Table 6.

Table 5. Number of equity, index and balanced fund evaluated better than S\&P500 Index

\begin{tabular}{|c|c|c|c|c|c|c|c|c|c|c|c|c|}
\hline Year & 2000 & $\mathbf{2 0 0 1}$ & $\mathbf{2 0 0 2}$ & $\mathbf{2 0 0 3}$ & $\mathbf{2 0 0 4}$ & $\mathbf{2 0 0 5}$ & $\mathbf{2 0 0 6}$ & $\mathbf{2 0 0 7}$ & $\mathbf{2 0 0 8}$ & $\mathbf{2 0 0 9}$ & $\mathbf{2 0 1 0}$ \\
\hline \multicolumn{10}{|c|}{ Equity funds (out of 84) } \\
\hline GH1 & 73 & 38 & 32 & 59 & 39 & 74 & 7 & 76 & 17 & 75 & 69 \\
\hline RAP & 73 & 20 & 0 & 84 & 84 & 84 & 84 & 84 & 0 & 84 & 84 \\
\hline Treynor & 68 & 24 & 1 & 84 & 84 & 84 & 84 & 84 & 0 & 84 & 84 \\
\hline Jensen & 68 & 36 & 26 & 69 & 44 & 74 & 12 & 76 & 14 & 78 & 78 \\
\hline \multicolumn{10}{|c|}{ Index funds (out of 30) } \\
\hline GH1 & 28 & 26 & 29 & 29 & 28 & 29 & 28 & 30 & 30 & 30 & 30 \\
\hline RAP & 28 & 1 & 0 & 30 & 30 & 30 & 30 & 30 & 0 & 30 & 30 \\
\hline Treynor & 27 & 1 & 0 & 30 & 30 & 30 & 30 & 30 & 0 & 30 & 30 \\
\hline Jensen & 27 & 23 & 27 & 29 & 29 & 29 & 28 & 30 & 30 & 30 & 30 \\
\hline & \multicolumn{10}{|c|}{ Balanced funds (out of 10) } \\
\hline GH1 & 4 & 6 & 3 & 6 & 5 & 8 & 4 & 5 & 1 & 10 & 6 \\
\hline RAP & 10 & 9 & 0 & 10 & 10 & 10 & 10 & 10 & 0 & 10 & 10 \\
\hline Treynor & 10 & 10 & 4 & 10 & 10 & 10 & 10 & 10 & 0 & 10 & 10 \\
\hline Jensen & 3 & 5 & 2 & 7 & 5 & 8 & 4 & 5 & 1 & 10 & 10 \\
\hline
\end{tabular}

Results in Table 5 show that there are pairs of measures that evaluate funds similarly. These pairs are GH1 and Jensen alpha, RAP and Treynor ratio for equity, index, balanced funds. Results suggest that S\&P500 Index performed better than equity and balanced funds in 2002 and 2008; better than index funds in 2001, 2002 and 2008.

Table 6. Number of bond and balanced fund evaluated better than 3 month T-Bills

\begin{tabular}{|} 
Measure Year & $\mathbf{2 0 0 0}$ & $\mathbf{2 0 0 1}$ & $\mathbf{2 0 0 2}$ & $\mathbf{2 0 0 3}$ & $\mathbf{2 0 0 4}$ & $\mathbf{2 0 0 5}$ & $\mathbf{2 0 0 6}$ & $\mathbf{2 0 0 7}$ & $\mathbf{2 0 0 8}$ & $\mathbf{2 0 0 9}$ & $\mathbf{2 0 1 0}$ \\
\hline \multicolumn{10}{|c|}{ Bond funds (out of 29) } \\
\hline GH1 & 2 & 19 & 1 & 20 & 6 & 4 & 9 & 1 & 0 & 27 & 22 \\
\hline RAP & 26 & 24 & 23 & 9 & 2 & 0 & 3 & 4 & 2 & 27 & 22 \\
\hline Treynor & 26 & 26 & 29 & 26 & 26 & 4 & 6 & 19 & 7 & 28 & 27 \\
\hline Jensen & 3 & 23 & 6 & 21 & 12 & 4 & 9 & 3 & 0 & 27 & 24 \\
\hline \multicolumn{10}{|c|}{ Balanced funds (out of 10) } \\
\hline GH1 & 4 & 6 & 3 & 6 & 5 & 8 & 4 & 5 & 1 & 10 & 6 \\
\hline RAP & 2 & 0 & 0 & 10 & 8 & 1 & 9 & 5 & 0 & 10 & 10 \\
\hline Treynor & 2 & 0 & 0 & 10 & 9 & 8 & 9 & 8 & 0 & 10 & 10 \\
\hline Jensen & 3 & 5 & 2 & 7 & 5 & 8 & 4 & 5 & 1 & 10 & 10 \\
\hline
\end{tabular}

Results in Table 6 support the previous findings about pairs of measures for balanced funds. We see more differences in bond fund evaluation. It is consistent with the results of correlation analysis. Results also suggest that 3 month T-Bills performed better than balanced funds in $2000-2002$ and 2008; better than most of bond funds in 2005, 2006 and 2008.

\section{Conclusions and discussion}

In this paper, we have evaluated the performance of 84 equity (Growth), 30 index, 29 bond (Government/Corporate bond) and 10 balanced funds over the period 2000-2010. All selected funds have been in operation throughout the test period. We used four performance evaluation measures: Modigliani \& Modigliani RAP (RAP), Graham - Harvey 1 (GH1), Treynor ratio, Jensen alpha.

The findings of correlation analysis are: 
- For equity and balanced funds, the strength of association for all measures is very strong and statistically significant. We find no dependence neither on year of analysis nor market conditions while evaluating the performance of selected equity and balanced funds.

- For index funds, there is a strong statistically significant relation between GH1 and RAP, Treynor ratio and Jensen alpha. There is statistically significant relation tending to moderate for other pairs of measures depending on year chosen. We find insignificant dependence on year of analysis and market conditions while evaluating the performance of index funds.

- For bond funds, there is a strong statistically significant relation between GH1 and RAP measures. There is statistically significant relation ranging from strong to moderate for other measures depending on year of analysis. We find a more significant dependence on year of analysis and market conditions while evaluating the performance of bond funds compared to results of index, equity and balanced funds.

Results of comparing mutual fund performance with S\&P500 Index and 3 month T-Bills show that there are pairs of measures - GH1 and Jensen alpha, RAP and Treynor ratio - which evaluate equity, index and balanced funds similarly. There are more differences in bond fund evaluation.

As we see this research is limited to four types of U.S. mutual funds only and hence the findings can only be related to the U.S. funds tested. An interesting aspect for a future study would be to examine an extended sample of fund types and longer period.

\section{References}

1. The Board of Governors of the Federal Reserve System. Economic Research \& Data, Selected Interest Rates. http://www.federalreserve.gov/releases/h15/data.htm. Accessed: December 5, 2011.

2. Brown, S. J., \& Goetzmann, W. N. (1995). Performance Persistence. The Journal of Finance, 50 (2), 679-698.

3. Carhart, M. M. (1997). On Persistence in Mutual Fund Performance. The Journal of Finance, 52(1), 57-82.

4. Chen Y., \& Ferson W., \& Peters H. (2010). Measuring the Timing Ability and Performance of Bond Mutual Funds. Journal of Financial Economics, 98(1), 72-89.

5. Chevalier, J., \& Ellison, G. (1999). Are Some Mutual Fund Managers Better Than Others? Cross-Sectional Patterns in Behavior and Performance. The Journal of Finance, 54, 875-899.

6. Cogneau, P., \& Hubner, G. (2009). The 101 Ways to Measure Portfolio Performance. Retrieved from SSRN: http://ssrn.com/abstract=1326076

7. Davis J. L. (2001). Mutual Fund Performance and Manager Style. Financial Analysts Journal, 57(1), 19-27.

8. Eling M., \& Schuhmacher, F. (2007). Does the choice of performance measure influence the evaluation of hedge funds?. Journal of Banking \& Finance, 31(9), 2632-2647.

9. Elton E. J.,\& Gruber, M. J., \& Green, T. C. (2007). The Impact of Mutual Fund Family Membership on Investor Risk. Journal of Financial and Quantitative Analysis, 42, 257-277.

10. Fletcher, J. (1995). An Examination of the Selectivity and Market Timing Performance of UK Unit Trusts. Journal of Business Finance \& Accounting, 22, 143-156.

11. Glassman, D. A., \& Riddick, L. A. (2006). Market Timing by Global Fund Managers. Journal of International Money and Finance, 25(7), 1029-1050.

12. Graham, J. R., \& Campbell, R. H. (1997). Grading the Performance of Market-Timing Newsletters. Financial Analysts Journal, 53(6), 54-66.

13. Hahn, C., \& Wagner, F. P., \& Pfingsten, A. (2002). An Empirical Investigation of the Rank Correlation Between Different Risk Measures. EFA 2002 Berlin Meetings Presented Paper, Westfaelische Wilhelms Universitaet Muenster Discussion Paper No. 02-01.

14. Hendricks, D., \& Patel, J., \& Zeckhauser, R. (1993). Hot Hands in Mutual Funds: Short-Run Persistence of Relative Performance, 1974-1988. The Journal of Finance, 48(1), 93-130.

15. Henriksson, R. D., \& Merton, R. C. (1981). On Market Timing and Investment Performance. II. Statistical Procedures for Evaluating Forecasting Skills. The Journal of Business, 54(4), 513-533.

16. Huij, J., \& Verbeek, M.(2007). Cross-sectional learning and short-run persistence in mutual fund performance. Journal of Banking \& Finance, 31(3), 973-997.

17. Indro, D. C., \& Jiang, C. X., \& Hu, M. Y.,\& Lee, W. Y. (1999). Mutual Fund Performance: Does Fund Size Matter? Financial Analysts Journal, 55(3), 74-87.

18. The Investment Company Institute. (2011). Investment Company Fact Book. (51st ed.). Retrieved from: http://www.ici.org/pdf/2011_factbook.pdf 
19. The Investment Company Institute. (2006). Investment Company Fact Book. (46th ed.). Retrieved from: http://www.icifactbook.org/2006/pdf/2006_factbook.pdf

20. Jensen, M. C. (1968). The Performance of Mutual Funds in the Period 1945-1964. The Journal of Finance, 23(2), 389-416.

21. Jiang, G. J., \& Yao, T.,\& Yu, T. (2007). Do Mutual Funds Time the Market? Evidence from Portfolio Holdings. Journal of Financial Economics, 86(3), 724-758.

22. Massa, M. (2003). How do family strategies affect fund performance? When performance-maximization is not the only game in town. Journal of Financial Economics, 67(2), 249-304.

23. Merton, R. C. (1981). On Market Timing and Investment Performance. I. An Equilibrium Theory of Value for Market Forecasts. The Journal of Business, 54(3), 363-406.

24. Modigliani, F., \& Modigliani, L. (1997). Risk-Adjusted Performance - How to Measure it and Why. The Journal of Portfolio Management, 23(2), 45-54.

25. The National Bureau of Economic Research (NBER). Official Business Cycle Dates. http://www.nber.org/cycles/cyclesmain.html. Accessed: December 11, 2011.

26. Pollet, J. M., \& Wilson, M. (2008). How Does Size Affect Mutual Fund Behavior?. The Journal of Finance, 63, 2941-2969.

27. Prather, L., \& Bertin, W. J., \& Henker, T. (2004). Mutual fund characteristics, managerial attributes, and fund performance. Review of Financial Economics, 13(4), 305-326.

28. Scholz, H., \& Wilkens, M. (2005). A Jigsaw Puzzle of Basic Risk-Adjusted Performance Measures. The Journal of Performance Measurement, 9(3), 57-64.

29. The Securities Commission of the Republic of Lithuania. (2011). $2010 \mathrm{~m}$. Vertybiniu popieriu komisijos veiklos ataskaita ir finansinių priemonių rinkos tendencijos. Retrieved from: http://www.lb.lt/2010_metu_veiklos_ataskaita_1

30. Sharpe, W. F. (1966). Mutual Fund Performance. The Journal of Business, 39(1), 119-138.

31. Simons, K. (1998). Risk - adjusted performance of mutual funds. New England Economic Review, Federal Reserve Bank of Boston, issue Sep, 33-48. Retrieved http://www.bostonfed.org/economic/neer/neer1998/neer598b.pdf

32. Treynor, J. L. (1965). How to Rate Management of Investment Funds. Harvard Business Review, 43, 63-75.

33. Yahoo! Finance. http://finance.yahoo.com/. Accessed: December 1, 2011. 